\title{
Family Planning in a Family Health Unit
}

\author{
Luzia Aparecida dos Santos Pierre ${ }^{1}$ \\ Maria José Clapis²
}

The aim of this study was to identify the care provided by health professionals who work in family planning, in a Family Health Unit in the municipality of Ribeirao Preto, São Paulo. This was a descriptive, cross-sectional and quali-quantitative study. Data were collected through interviews with 11 health professionals. The results revealed that most professionals had not received training in family planning, and that information about contraceptive methods is transmitted in an individual way, having women as the target-public. The contraceptive methods which the professionals suggest and offer more are those considered most effective. These findings indicate that family planning care at the Family Health Unit needs to be adjusted not only to ensure quality of service, but also to ensure sexual and reproductive rights.

Descriptors: Women's Health; Family Planning Services; Family Health Program; Nursing.

\footnotetext{
${ }^{1}$ Nurse-Midwife, Master's Student in Nursing, Escola de Enfermagem de Ribeirão Preto, Universidade de São Paulo, WHO Collaborating Centre for Nursing Research Development, SP, Brazil. E-mail: luzan@usp.br.

${ }^{2}$ RN, Ph.D. in Nursing, Associate Professor, Escola de Enfermagem de Ribeirão Preto, Universidade de São Paulo, WHO Collaborating Centre for Nursing Research Development, SP, Brazil. E-mail: maclapis@eerp.usp.br.
} 


\section{Planejamento familiar em Unidade de Saúde da Família}

O objetivo deste estudo foi identificar a assistência oferecida pelos profissionais de saúde que atuam em planejamento familiar, em uma Unidade de Saúde da Família, no município de Ribeirão Preto, São Paulo. Trata-se de estudo descritivo, com corte transversal e abordagem quali-quantitativa. Os dados foram coletados por meio de entrevista com 11 profissionais da saúde. Os resultados revelaram que a maioria dos profissionais não recebeu capacitação em planejamento familiar, sendo que a informação sobre os métodos anticoncepcionais é transmitida de forma individual, tendo como público-alvo as mulheres. Os métodos anticoncepcionais, considerados mais eficazes, são aqueles sobre os quais os profissionais mais orientam e oferecem. Os achados apontam que a assistência em planejamento familiar na Unidade de Saúde da Família necessita de adequações, não só para assegurar a qualidade do serviço prestado como também para assegurar direitos sexuais e reprodutivos.

Descritores: Saúde da Mulher; Serviços de Planejamento Familiar; Programa Saúde da Família; Enfermagem.

\section{Planificación familiar en Unidad de Salud de la Familia}

El objetivo de este estudio fue identificar la asistencia ofrecida por los profesionales de la salud que actúan en la planificación familiar, en una Unidad de Salud de la Familia, en el municipio de Ribeirao Preto, Sao Paulo. Se trata de un estudio descriptivo con corte transversal y abordaje cuali-cuantitativo. Los datos fueron recolectados por medio de entrevista con 11 profesionales de la salud. Los resultados revelaron que la mayoría de los profesionales no recibió capacitación en planificación familiar, siendo que la información sobre los métodos anti-conceptivos es trasmitida de forma individual, teniendo como público objetivo a las mujeres. Los métodos anticonceptivos considerados más eficaces son aquellos sobre los cuales los profesionales más orientan y ofrecen. Los hallazgos apuntan que la asistencia en planificación familiar en la Unidad de Salud de la Familia necesita de adecuaciones, no sólo para asegurar la calidad del servicio prestado, como también para asegurar los derechos sexuales y reproductivos.

Descriptores: Salud de la Mujer; Servicios de Planificación Familiar; Programa de Salud Familiar; Enfermería.

\section{Introduction}

Family planning is a right of women, men and couples and is supported in Article 226, paragraph 7 of the Federal Constitution ${ }^{(1)}$, and by Law 9263 of $1996^{(2)}$, which regulates it. It is the responsibility of the State to provide educational and technological resources to exercise this right $^{(1)}$, as well as health professionals trained to develop actions that address conception and contraception $^{(3)}$. It is therefore essential that professional training provides the development of skills for the provision of adequate information on family planning, to meet the needs of the clients from the perspective of sexual and reproductive rights, and provides continuous updates $^{(4)}$.

Adequate information on family planning is of fundamental importance, since it allows the client to exercise their rights, to recognize contraceptive methods and to make independent choices. It should include guidance regarding methods, as well as sexual and reproductive health ${ }^{(5)}$. In addition, health services must have methods and techniques for controlling fertility. The provision of contraceptive methods, with a view to autonomous choice, points to the need for the services 
to provide a wide range of options so that clients can freely, safely and reliably choose the most appropriate method for the different times of their reproductive life, according to their history of health and adaptation(5).

Difficulties for the effective implementation of family planning, with regard to information and provision of contraception, have been observed in some Brazilian municipalities ${ }^{(6-7)}$. These difficulties must be recognized and converted into the effective use of these services. Thus, to delineate the overview of this assistance can contribute to the planning and programming of activities in order to review priorities, support decision making and contribute to the achievement of better results in terms of impact on the sexual and reproductive health of the population.

In Brazil, although family planning is the responsibility of all levels of health care, it is mainly developed in Primary Health Care through the Family Health Strategy ${ }^{(5)}$, which has among its guidelines, community participation, considered a factor which allows the needs of people to be identified and met. Thus, clients can control the actions of health, increasing the potential for the reconstruction of practices, in order to meet their needs and expectations and, consequently, triggering the obligation of the managers to evaluate the quality of care offered. From this perspective, in the late 1980s, a theoretical framework ${ }^{(8)}$ was proposed in which the qualitative characterization of the assistance offered in family planning was suggested. Six elements of quality compose this theoretical framework: the provision and free choice of contraceptive methods, the information given to the clients, the technical expertise of the professionals, the interpersonal relationships between clients and professionals, monitoring of the clients who make use of methods, and the integration of family planning with reproductive health care.

In Ribeirao Preto, although family planning has been regulated by the Municipal Health Secretariat since $1999^{(9)}$, published data that allow analysis of the development of their actions are not to be found. Given this fact, the following questions arise: what family planning actions are developed in the municipality, specifically in the Family Health Unit? Do the professionals who work in this context receive training? What information and contraceptive methods are available to the clients of these services? What are the perceptions of the professionals regarding the family planning service offered?

This study was developed in order to understand this care, from the perspective of health professionals, in a Family Health Unit of Ribeirao Preto, taking into account the elements of quality: provision and free choice of methods, and information available to clients on family planning.

\section{Aims}

The aim of this study was to identify the care provided by the health professionals who work in family planning in a Family Health Unit of the city of Ribeirao Preto, São Paulo.

\section{Method}

This was a descriptive, cross-sectional and qualiquantitative study. It was developed in a Family Health Unit in the municipality of Ribeirao Preto, linked to the Faculty of Medicine of Ribeirao Preto of the University of São Paulo. The team was composed of 13 professionals, namely: a general physician, three resident physicians, a dentist, a nurse, two auxiliary nurses and five community health agents. A total of 11 professionals participated in the survey. A resident physician had changed the internship site and the dentist who was in the process of retirement did not agree to participate in the study.

To collect data, an instrument was used that was developed based on the literature review. The instrument was validated, as to its content and appearance, by four health professionals knowledgeable in the theoretical framework (two nurses and two physicians). The interviews were conducted in the workplace and previously scheduled with each professional. The data were codified, as ascending numbers of: E1, E2 ... and so on. The research project was sent to the Family Health Unit team for their consideration and then for review by the Research Ethics Committee of the College of Nursing, University of São Paulo of Ribeirão Preto, receiving approval (Protocol no 0806/2007). Participants were presented with the terms of free prior informed consent and were assured of their anonymity. The responses were systematized into a database and categorized to form the analysis, considering recurrent frequently expressed opinions, dissent and consensus. Quantitative data were subjected to descriptive analysis and presented as absolute frequencies, and qualitative data were subjected to content analysis ${ }^{(10)}$.

\section{Results and Discussion}

Study participants were three physicians (one general and two residents), a nurse, two auxiliary nurses and five 
community health agents. Ten interviewees were female and one male. They ranged from 27 to 50 years of age with a mean of 37 years. Five interviewees had completed a higher education course, one had an incomplete higher education and five complete high school education. The length of employment of the interviewees in the Family Health Unit ranged from one to eight years, with a mean time of four years and eight months, while the length of time operating in family planning varied from one to 20 years, with a mean of seven years. These data demonstrate the previous experience of the interviewees in family planning. The family planning issue was addressed in the curriculum of graduate courses for physicians and nurses, as well as in the professionalization course of an auxiliary nurse. The training course for community health agents, did not contemplate the issue, although the family was focused on.

During the work in the Family Health Unit, the general physician reported having participated in training in family planning six years ago, and the nurse did not remember how long ago s/he participated in the training offered by the Municipal and State Health Secretariats, an auxiliary nurse did not remember whether s/he had participated in training on this topic, while the remaining interviewees reported not having participated. The data suggest that the Family Health Unit was not a site of training of health professionals in family planning.

The community health agents are assigned educative functions in family planning ${ }^{(11-12)}$ together with the community they monitor, however, in this study, these professionals had not had the opportunity for discussion or training on the topic. Professional training is considered a means of developing competence ${ }^{(4)}$. In family planning, the lack of technical competence can be attributed to a lack of teaching of this content in the professionalization curricula, to a focus on contraceptive methods, to the neglect of aspects such as human sexuality and communication techniques, the lack of retraining of the professional and offers of training by the managers, and the concentration of the actions of family planning on the physician figure, neglecting the other professionals ${ }^{(13)}$.

The Ministry of Health(14), in the Family Health Teams evaluation report, revealed that more than half of physicians and nurses working in women's health, were not trained for action in family planning, treatment of gynecological disorders, prevention of cervical cancer and pre-natal consultations. Study on the topic showed that training in family planning takes place in an uneven and insufficient way. In addition, health professionals do not perceive it as part of the Primary Health Care, of a preventive character for the health of the woman and child(15). However, the training in family planning of health professionals working in Primary Health Care is a government priority ${ }^{(11)}$. This training was proposed by the Program of Integral Attention to Women's Health in the 80 's, but over the years has had limited effectiveness and has suffered discontinuity ${ }^{(7)}$. In 2004, the Ministry of Health proposed a National Policy of Permanent Education in Health, aiming to transform the professional practices through the problematization of the work process, taking into consideration the health needs of individuals, of populations, of sector management and of social control in health. However, a study subsequent to the implementation of this policy revealed that the number of educational activities implemented is not adequate, and that a significant percentage (31.7\%) of health professionals do not participate in any educational $\operatorname{activity}^{(16)}$.

Regarding educational activities in family planning, the professionals reported that they are developed primarily in an individual way during domicile visits, or at the site of the Family Health Unit, through medical or nursing consultations and are sometimes carried out in groups in the health service, in schools and at local community meetings. It was perceived that there is a predominance of individual attention, distanced from the more collective focus, which is the proposal of the Family Health Program. Women constitute the targetpublic of the educational activities concerning family planning in this service. Other studies ${ }^{(15,17)}$ showed the prevalence of sexual health and reproductive services directed towards women. However, it is understood here to be important to implement the spaces for the discussion of family planning for men, in collaboration with women, in view of the exercise of sexual and reproductive rights. Among the educational activities of family planning, counseling on contraceptive methods is the main topic considered. Aspects related to sexual and reproductive health are neglected, i.e. information about human sexuality, sexually transmitted diseases, human immunodeficiency virus, cervical cancer, responsible parenthood and motherhood are less considered. There was reference to the information on conception.

The information on contraceptive methods available to clients, are described in Table 1. A structured question was used to collect this information. 
Table 1 - Distribution of information regarding contraceptive methods available to clients, Ribeirão Preto, 2008

\begin{tabular}{|c|c|c|c|c|c|c|}
\hline \multirow[t]{2}{*}{$\mathrm{ACM}$} & How to use & Efficacy & Who can use & Collateral effects & $\begin{array}{c}\text { Sexual life } \\
\text { implications }\end{array}$ & $\begin{array}{c}\text { Available/ } \\
\text { agreed* }^{*}\end{array}$ \\
\hline & $\mathrm{n}^{\circ}$ & $n^{\circ}$ & $n^{\circ}$ & $n^{\circ}$ & $n^{\circ}$ & $n^{\circ}$ \\
\hline The pill & 10 & 9 & 8 & 9 & 10 & 11 \\
\hline Mini-pill & 8 & 7 & 6 & 7 & 8 & 9 \\
\hline Hormone injection & 9 & 8 & 7 & 8 & 9 & 11 \\
\hline The morning after pill & 6 & 6 & 5 & 6 & 6 & 4 \\
\hline IUD & 10 & 9 & 8 & 9 & 10 & 11 \\
\hline Diaphragm & 7 & 6 & 5 & 6 & 7 & 1 \\
\hline Male condom & 11 & 10 & 8 & 9 & 11 & 11 \\
\hline Female condom & 10 & 9 & 8 & 9 & 10 & 5 \\
\hline LAM (breastfeeding) & 5 & 5 & 4 & 5 & 5 & 4 \\
\hline Withdrawal method & 2 & 2 & 2 & 2 & 2 & 1 \\
\hline Rhythm Method & 3 & 3 & 2 & 3 & 3 & 2 \\
\hline Cervical mucus monitoring & 1 & 1 & 1 & 1 & 1 & - \\
\hline Temperature monitoring & - & - & - & - & - & - \\
\hline Tubal ligation & 11 & 10 & 8 & 9 & 11 & 11 \\
\hline Vasectomy & 11 & 10 & 8 & 9 & 11 & 11 \\
\hline
\end{tabular}

* Agreed: contraceptive method not available in the Family Health Strategy Unit, however, offered to clients through referral to another health service, or by encouraging behavior that affects fertility control (behavioral methods).

The mode of use, efficacy, collateral effects, the implications for sexual life and the availability of methods: the pill, mini-pill, injectable hormones, male condoms, tubal ligation and vasectomy comprise the guidance offered to clients by most of the interviewees. The methods morning after pill, diaphragm and female condom are also suggested, but are offered or agreed to less in the Family Health Unit. This fact is not related to the lack of methods, since the interviewees reported that there is rarely a lack thereof. Exclusive breastfeeding (LAM), withdrawal, the rhythm method and cervical mucus monitoring are less suggested, offered or agreed to in the health service (Table 1 ).

The contraceptive methods that, scientifically, present the higher contraceptive efficacy are the most suggested and offered by the interviewees to the clients, with those of lower efficacy being less suggested and offered. This attitude may be related to the lack of knowledge of professionals about the methods, i.e. to inadequate professional technical competence ${ }^{(5)}$. The data suggest that family planning assistance in this service does not offer women the knowledge of the diversity of contraceptives. According to the theoretical framework ${ }^{(5)}$ that characterizes the quality care in family planning, the clients should receive information about the diversity of methods equally and have access to them in order to freely, safely, reliably and appropriately choose, in different moments of reproductive life, according to history of health and adaptation to the method ${ }^{(5,13)}$.

Despite these results, the majority of interviewees (10) found that contraceptives are provided in a free and informed way.
... people are informed and can choose the method (E3) .. the person chooses the method that they want, it is the option of the person (E10) ... they have information and easy access to contraceptive methods (E1).

It should be highlighted here that the offer and free choice of contraceptive methods is a right ${ }^{(1-2,8)}$, and information about the diversity of them and their availability for fertility control are key elements for adherence to contraceptive use ${ }^{(7-8)}$.

One of the interviewees reported that in some situations, it is difficult to guarantee the offer and the free choice of contraceptive methods, because they depend on other services.

I think it's just informed ...it is not free because sometimes the woman cannot have, for example, the IUD or definitive methods (E8).

It is noteworthy that the family planning services should not necessarily have all the methods, but rather those that clients use most, or so they can meet the needs on a geographical basis so that clients have equal access to a reasonable variety of them ${ }^{(5,8)}$, thus, it is necessary to recognize the contraceptive needs of the clients.

Other interviewees (2) reported that there are medical conditions that contraindicate certain contraceptives and thus women are advised by doctors about the methods they are able use.

... we offer contraceptives according to the option of individuals, however, some medical conditions do not allow this choice (E2). We talk about all the methods and it is the woman who chooses together with the physician (E4). 
The clinical assessment, followed by guidance regarding all the methods is of great importance, because the offer of contraceptives should be free, yet, informed and advised. Thus, the clients should know what methods they can use and which they cannot, this choice should occur according to the characteristics, needs and living conditions of each woman ${ }^{(5,7)}$.

The interviewees (3) also reported that the choice of method may be influenced by the income of the client and their availability in the health service, confirming the results of another study ${ }^{(18)}$. Furthermore, the adaptation of women to the contraceptive can also influence this choice.

... we pass information on all methods and the patients choose according to their reality, or according to their income, the availability of the methods in the service, their adaptation to the method (E5) ... the pros and cons are talked about, the price among other things, according to the client, so they choose from those which they can use (E11).

These statements reinforce the perception that the choice of a contraceptive method, in the Family Health Unit, does not address the variety, as clients choose them according to income, with the price and availability in the service, therefore, this does not constitute a free choice. Lack of access to medicines in the family health care service was highlighted in research with users $^{(19)}$ and may represent a risk for ineffective use of contraceptive methods ${ }^{(18)}$. The view that the physician knows what is best for the client, ignoring the autonomy of choice of the latter, emerged within the interviewees' statements.

The center (health service) is working with disease prevention and health promotion, and the method that is best for the woman is that which the doctor determines (E7).

Authoritarian or paternalistic attitudes on the part of health professionals, as well as the lack of appreciation for the real needs, rights and ability to decide of the client may be linked to a deficiency in training(5). Interviewees believe that, for quality to exist in family planning, it is necessary to encourage listening to the needs of clients; as well as to provide guidance on contraceptive methods.

I think we have to listen to the patient more, their complaints, their needs. What is good for one may not be good for another (E7) ... to be always available to talk about the subject, not to miss the opportunity (E2). When there is a bond with the woman, we know their reality, the conditions of the individuals (E1).

The link between professional and client is also referred to as an important element for the quality of care $^{(5,8)}$. The interviewees believed that family planning training is essential for the development of educational activities and they highlighted the needs of the service.

... the professionals should be well informed and prepared, involved and know the importance of the subject (E2). It (the health service) should better prepare the employee to provide more information, more didactic, dummies, illustrative material to arouse curiosity, not only material in itself ... more teaching through group dynamics, material ... handouts ... drawings ... the population search a lot for advice on family planning (E8).

The lack of resource material, also evidenced in another study ${ }^{(15)}$, can negatively influence the understanding of women in family planning, not contributing to the freedom of choice nor the continuity of use of the method, since the visual resource is essential for the assimilation of information ${ }^{(5)}$. The provision of information and of contraceptive methods, especially for clients with low purchasing power, the efficacy of the method and the ready supply of condoms were cited as factors related to the quality of care.

First, guidance regarding the method and, second, the availability of the methods in the services. Methods should be offered in the health network to assist the needy patients (E5). It should provide all the more used methods, the most effective, it must have easy access, prompt delivery of the method, without having to go through clinical consultation to obtain condoms ... (E9).

Advice about the impact of unplanned pregnancy, sexuality separated from pregnancy, and the inclusion of the sexual partner in family planning decisions, are also cited as important for the quality of care.

It should have counseling. Addressing the reflection of having children or not, which should an individual decision. Children should be planned ... To plan a child independent from sexuality. Then you must have guidance on sexuality, sexual health. To make women think about the method, why the partner should participate, to use what is most appropriate (E3).

Professionals (3) understood that the family planning offered by the Family Health Unit has quality and that the service is a model; although they believed it could be improved.

I think it has quality, it has the options of methods. People sometimes, use the method incorrectly, but we advise them again. Since they want to plan they have to do it right, it is their responsibility (E10). I think this service is a model, perhaps the resolution of cases of tubal ligation and vasectomy reversal could be improved (E1). I don't know what has to be done, but it can be improved, I cannot say it is perfect, but I think it is good. The nurses and physicians are competent (E7).

It is noteworthy that these statements reveal 
the inobservance of the co-responsibility of the professionals for the health of the clients, and suggest the precariousness of family planning care, such as the request for vasectomy reversal. Most interviewees reported the need to improve some aspect of the care, such as the provision of contraceptive methods and training for community health agents in family planning, as they are cited as components of the team that need more training.

...to have more methods, most of them, because there were times when it didn't have method and pregnancy occurred. Could have more training for the team of community health agents (E2). The government should offer more methods that they do not have in the health network, such as the implant (E11) ... preparing the community health agents more, providing more material, more continuing education ... we have access to the methods (E8) ... The agents could receive further guidance, for example, on Tuesdays, at the continuing education, we could emphasize this subject more ... (E2). In the training for community health agents they talk a lot about family, but do not talk about family planning (E10).

The achievement of guidance in groups for adolescents, women and couples is perceived as a way to qualify the family planning care, although there are difficulties to implement groups.

... maybe some group, even though sometimes we do not have adherence... a group for adolescents would be interesting, it would be very good ... adolescents are bubbling, but it is difficult to catch, it is difficult even for adults (E6). Here, perhaps there is a lack of groups for women's health, groups for couples. I think regarding the consultation it is working ok (E11). Group orientation is more difficult because sometimes people do not like to talk about their needs, preferences, better to talk individually ... So a group for women only is interesting, because mixed groups are much more difficult (E6).

It is noted here that the interviewees have perceived shortcomings of the family planning service and envision solutions in the prospect of a quality service.

\section{Conclusions}

It can be concluded from this study that there is a need for training in family planning for the professionals of the Family Health Unit, as well as an increase in the provision of group educational activities for the clients on a continuous basis, including men and all the professionals of the health team in the educational activities. The information provided in family planning should not only emphasize the contraceptive methods considered effective, but should address and provide the variety of methods. Aspects related to sexual and reproductive health are shown to be indispensable and should be elucidated.

The professionals of the Family Health Unit acknowledge some shortcomings in the care offered in family planning and contemplate actions to overcome these weaknesses. It is necessary for health managers to implement actions to ensure the provision of methods to encourage free and informed client choice, converging with the theoretical framework that characterizes quality care in family planning from the perspective of reproductive and sexual rights.

Further studies evaluating the quality of care in family planning should be developed considering the lack thereof, and the relevance of the topic.

\section{References}

1. Constituição da Republica Federativa do Brasil (BR). Art. 226, parágrafo 7, Cap 7: Da Família, Da Criança, Do Adolescente e Do Idoso. Brasília (DF); Senado Federal; 1988.

2. Lei n. 9.263 de 12 de janeiro 1996. Regula Planejamento Familiar. Diário Oficial da União, Brasília (DF); 1996.

3. Ministério da Saúde (BR). Cadernos de Atenção Básica: programa Saúde da Família: caderno 1: a implantação da unidade de saúde da família a traduzir. Brasília (DF): Secretaria de Políticas de Saúde. Departamento de Atenção Básica; Ministério da Saúde; 2000. 44 p.

4. Moura ERF, Silva RM. Competência profissional e assistência em anticoncepção. Cad Saúde Pública. 2005;39(5):795-801.

5. Moura ERF. Assistência ao Planejamento Familiar na perspectiva de clientes e enfermeiros do programa de saúde da família. [tese de doutorado]. Fortaleza (CE): Faculdade de Farmácia, Odontologia e Enfermagem da Universidade Federal do Ceará; 2003. 136 p.
6. Ministério da Saúde (BR). Política nacional de atenção integral à saúde da mulher: princípios e diretrizes. Brasília (DF): Secretaria de Atenção à Saúde. Departamento de Ações Programáticas Estratégicas; Ministério da Saúde; 2009. 82 p.

7. Osis MJD, Duarte GA, Crespo ER, Espejo E, Pádua KS. Escolha de métodos contraceptivos entre usuárias de um serviço público de saúde. Cad Saúde Pública. 2004;20(6):1586-94.

8. Bruce J. Fundamental elements of the quality of care: a simple framework. Stud Fam Plann. 1990;21(2):61-91.

9. Vieira EM, Fábio SV, Gueleri W, Picado MP, Yoshinaga E, Souza

L. Características dos candidatos à esterilização cirúrgica e os fatores associados ao tipo de procedimento. Cad Saúde Publica. 2005;21(6):1785-91.

10. Bardin L. Análise de conteúdo. São Paulo: Edições 70; 1977. $226 \mathrm{p}$ 
11. Ministério da Saúde (BR). Direitos Sexuais e Direitos Reprodutivos: uma prioridade de governo. Brasília (DF): Secretaria de Atenção à Saúde. Departamento de Ações Programáticas Estratégicas; Ministério da Saúde; 2005. 24 p. 12. Ministério da Saúde (BR). Anexo - Perfil de competências profissionais do agente comunitário de saúde. 2010. [acesso: 01 set 2010]. Disponível em: http:// portal.saude.gov.br/portal/ arquivos/pdf/anexo_perfil_competencias_acs.pdf

13. Díaz M, Díaz J. Qualidade de atenção em saúde sexual e reprodutiva: estratégias para mudança. In: Galvão L, Díaz J, organizadores. Saúde Sexual e Reprodutiva no Brasil: dilemas e desafios. São Paulo (SP): Hucitec-Population Council; 1999. p. 209-36.

14. Ministério da Saúde (BR). Avaliação normativa do Programa de Saúde da Família no Brasil: monitoramento da implantação e funcionamento das equipes de saúde da família: 2001-2002. Brasília (DF): Secretaria de Atenção à Saúde. Departamento de Atenção Básica; Ministério da Saúde; 2004. 140 p.

15. Osis MJD, Faúndes A, Makuch MY, Mello MB, Sousa MH, Araújo MJO. Atenção ao planejamento familiar no Brasil hoje: reflexões sobre os resultados de uma pesquisa. Cad. Saúde Publica. 2006; 22(11):2481-90.
16. Muforose NT, Rizzoto MLF, Muzzolon ABF, Nicola AF. Diagnóstico da situação dos trabalhadores em saúde e o processo de formação no pólo regional educação permanente em saúde. Rev. Latino-Am. Enfermagem [internet]. 2009. [acesso: 01 set 2010];17(3): 314-20. Disponível em: http:// www.scielo.br/scielo.php?pid=S010411692009000300006\&scri pt=sci_arttext\&tlng $=$ pt

17. Marcolino C, Gastrolo EP. As visões feminina e masculina acerca da participação de mulheres e homens no planejamento familiar. Rev. Latino-Am. Enfermagem. 2001; 9(3):77-82.

18. Camiá GEK, Marin HF, Barbieri M. Diagnósticos de enfermagem em mulheres que freqüentam serviço de planejamento familiar. Rev. Latino-Am. Enfermagem. 2001;9(2):26-34.

19. Shimizu HE, Rosales $C$. A atenção à saúde da família sob a ótica do usuário. Rev. Latino-Am. Enfermagem [online]. 2008. [acesso em: 01 set 2010];16(5):883-8. Disponível em: http:// www.scielo.br/scielo.php?script=sci_arttext\&pid=S0104116920 08000500014\&lang $=$ pt\&tlng $=p t$ 